\title{
SOLUTIONS OF PHYSICAL DEVELOPMENT FOR JUNIOR HIGH SCHOOL STUDENTS IN HANOI'S SUBURBS
}

\author{
Phung Xuan Dungi \\ Dr., Hanoi University of \\ Physical Education and Sports, \\ Vietnam
}

\begin{abstract}
:
The article is written based on legal, practical, and philosophical documents, to offer some physical development solutions for students in junior high schools in Hanoi's suburbs. By researching theoretical and practical bases, and employing traditional approaches in the field of sports science research, the article constructed 10 solutions divided into 5 groups relating to five aspects: awareness, facilities, quality, internalexternal PE programs, and organizational structure. It is ensured that the solutions mentioned in the article are feasible enough for the physical growth of junior high school pupils in Hanoi's suburbs.
\end{abstract}

Keywords: solution; physical development; students; junior high schools; Hanoi

\section{Introduction}

Physical education is particularly important for junior high school children since this is the age when they are making physical and mental leaps, progressively transitioning from childhood to the next stage. The upper stages of the child development process deliver the basic differences that influence all aspects involving physical, mental health, emotions, behaviors, and so on. As a result, the impact of the PE program on this age must be studied thoroughly. Only then will the children's bodies grow naturally according to their age and gender, laying the groundwork for healthy physical and mental development. The solutions presented in this article are guaranteed to be realistic for the physical development of junior high school students in Hanoi's suburbs.

It is generally held that having a good assessment of the current circumstance in order to propose solutions to improve physical fitness for high school students is a critical action, as well as a regular and significant duty of the entire society and the country's educational sector. Improving the quality and efficacy of physical education for secondary pupils, in particular, contributes to the training improvement of human

${ }^{i}$ Correspondence: phungxuandung@gmail.com 
resources for comprehensive and long-term growth, advancing the country's industrialization and modernization goals. Hence, PE has become a required subject in almost all schools, particularly in lower secondary schools, as stated in Article 41 of the Constitution of the Vietnam social republic of 1992 (the Chairman of the State Council, 1992). Besides, Article 37 The Constitution of Vietnam in 2013 (valid from 01/01/2014) stipulates: "Children are protected, cared for, and educated by the State, family, and society;...", "Youths are facilitated by the State, family, and society to study, work, entertain, and develop physically and mentally,..." (the Chairman of the State Council, 2013).

An investigation of physical education in secondary schools in Hanoi's suburbs reveals that, for the most extent, all schools comply with the content of the Ministry of Education and Training's program. However, facilities in suburban regions are still restricted owing to the relatively large number of pupils in a class and a large amount of time is spent studying other cultural subjects, thus extracurricular activities are largely not yet completely implemented. As a result, the physical capacity of secondary school students in Hanoi's suburbs has been limited. Given the above facts, researching physical development for students in secondary schools in Hanoi's suburbs is incredibly important to improve the efficacy of physical education for students in lower secondary schools today. Therefore, I decided to carry out research on: "Solutions of physical development for junior high school students in Hanoi's suburbs".

The objective of this research is to offer some physical development solutions for students at secondary schools in Hanoi's suburbs based on the analysis of the current circumstances.

\section{Methodology}

- Theoretical reference: The author tended to synthesize documents and analyze the obtained data. The list of documents employed for research is presented in the section "References".

- Questionnaire and Survey: To improve the objectivity and accuracy of the data collected, the author and his collaborators created a questionnaire form and conduct direct interviews with experts, leaders, managers, pedagogues, and PE teachers who are currently working for junior high school students in the Hanoi suburbs with a hope to select and evaluate the feasibility of the solutions.

- Mathematical statistics: SPSS 22.0 and Microsoft Excel are used to interpret and analyze the data obtained throughout the research.

\subsection{Research participants}

- 90 specialists, leaders, managers, educators, and PE teachers who are currently engaged in secondary students' physical development in the suburbs of Hanoi were polled to offer solutions.

- 25 officers working at the Hanoi Department of Education; managers from secondary schools in the suburbs of Hanoi; and 83 PE teachers of secondary 
schools in the suburbs of Hanoi were interviewed were invited to examine the solutions' necessity and practicality.

\section{Research results}

\subsection{Building the solutions for the physical development of secondary students in} Hanoi's suburbs

\section{a. The foundation for coming up with the solutions}

The legal documents are employed to select solutions, based on the Party and State's perspectives on improving training quality in general, and the development of physical education and school sports in particular: Resolution of the X Party Congress, Resolution No. 29-NQ/TW, Resolution No. 08-NQ/TW, Law on Physical Training and Sports, Decision No. 2198/ QD-TTg, Decree No. 11/2015/ND-CP, Decision No. 2160/QD-TTg, Decision No. 1076/QD-TTg.

The analysis of the current circumstance is used to develop the solutions that are also in accordance with the objectives of the PE subject as well as the present conditions and facilities available at junior high schools in Hanoi's suburbs. On the basis of a review of both subjective and objective factors, the author discovered that the quality of the facilities, yards, equipment, the teachers' and staff's salaries, remuneration policies, the management of physical education and sports movements, the implementation of extratraining and voluntary extracurricular activities are the main elements affecting to the quality of PE and the development of students' physical capacity in Hanoi's suburbs nowadays.

Moreover, when presenting solutions, the author had to follow specific principles in terms of goal satisfaction, systematization, synchronization, inheritance and complementarity, practicability, and feasibility.

\section{b. Solution selection}

Based on the above foundations plus the discussion with many experts, the writer has selected 7 groups of solutions for students' physical development in Hanoi suburban secondary schools.

In order to gauge the practical basis of the solutions which had been identified through reference to relevant sources, the researcher conducted a number of direct interviews with those who were working in the PE sector at Hanoi suburban secondary schools; and a variety of indirect interviews by questionnaires with experts at the University of Sports and Physical Education, as well as face-to-face discussions with professionals. A total of 100 votes were circulated, with 90 votes collected (reaching the rate of 90 percent).

The content of the questionnaire and interviews, as well as the outcomes, are presented in Table 1. 
Table 1: Interview findings for selecting physical development solutions for students in secondary schools in Hanoi's suburbs $(n=90)$

\begin{tabular}{|c|c|c|c|c|c|c|c|}
\hline \multirow[t]{2}{*}{ Group } & \multirow[t]{2}{*}{ Solution } & \multicolumn{2}{|c|}{$\begin{array}{c}\text { Very } \\
\text { necessary }\end{array}$} & \multicolumn{2}{|c|}{ Necessary } & \multicolumn{2}{|c|}{ Needless } \\
\hline & & $\mathbf{n}$ & $\%$ & $\mathbf{n}$ & $\%$ & $\mathbf{n}$ & $\%$ \\
\hline 1 & $\begin{array}{l}\text { Group 1: Raise awareness and provide knowledge } \\
\text { about the role of physical education and the } \\
\text { benefits of physical exercise in improving health. }\end{array}$ & 89 & 98.9 & 1 & 1.1 & - & - \\
\hline \multirow[t]{3}{*}{2} & $\begin{array}{l}\text { Group 2: Renovate and upgrade material and } \\
\text { technical foundations, implement appropriate and } \\
\text { suitable mechanisms and policies: }\end{array}$ & & & & & & \\
\hline & $\begin{array}{l}\text { Item: Renovate and upgrade material and technical } \\
\text { foundations }\end{array}$ & 78 & 86.36 & 10 & 11.11 & 2 & 2,2 \\
\hline & $\begin{array}{l}\text { Item: Implement appropriate and suitable } \\
\text { mechanisms and policies }\end{array}$ & 82 & 91.11 & 8 & 8.89 & - & - \\
\hline \multirow[t]{4}{*}{3} & $\begin{array}{l}\text { Group 3: Upgrade PE program's content and } \\
\text { methods of teaching and examination }\end{array}$ & & & & & & \\
\hline & $\begin{array}{l}\text { Item: Upgrade PE program's content, increase the } \\
\text { movement volume throughout class time }\end{array}$ & 88 & 97.78 & 2 & 2.2 & - & - \\
\hline & $\begin{array}{l}\text { Item: Modify the methods of PE teaching in favor of } \\
\text { positivism, so increasing student engagement and } \\
\text { creativity. }\end{array}$ & 87 & 96.36 & 3 & 3.33 & - & - \\
\hline & $\begin{array}{l}\text { Item: Alter the ways of PE examination in favor of } \\
\text { classifying students' health, fitness and aptitude. }\end{array}$ & 82 & 91.11 & 8 & 8.89 & - & - \\
\hline 4 & $\begin{array}{l}\text { Group 4: Improve the organizational structure of } \\
\text { the Physical Education Department's } \\
\text { administration and teaching personnel. }\end{array}$ & 89 & 98.9 & 1 & 1.1 & - & - \\
\hline \multirow[t]{4}{*}{5} & $\begin{array}{l}\text { Group 5: Diversify the content and forms of } \\
\text { extracurricular sports activities in accordance with } \\
\text { PE goals. }\end{array}$ & & & & & & \\
\hline & $\begin{array}{l}\text { Item: Encourage every student to take part in at least } \\
\text { one sport. Increase the number of sports competitions to } \\
\text { create more opportunities for students to get into }\end{array}$ & 88 & 97.78 & 2 & 2.2 & - & - \\
\hline & $\begin{array}{l}\text { Item: Set up sports clubs for officials, teachers and } \\
\text { students of all grades in the form of socialization. }\end{array}$ & 86 & 95.56 & 4 & 4.44 & - & - \\
\hline & Item: Maintain and improve the quality of school teams & 83 & 92.22 & 7 & 7.78 & - & - \\
\hline 6 & $\begin{array}{l}\text { Group 6: Promote the socialization of in organizing } \\
\text { sports tournaments and building facilities }\end{array}$ & 15 & 16.36 & 30 & 33.33 & 45 & 50.00 \\
\hline 7 & $\begin{array}{l}\text { Group 7: Establish a volunteer team to guide } \\
\text { extracurricular sports training for classes and } \\
\text { grades within the school }\end{array}$ & 20 & 22.22 & 20 & 22.22 & 50 & 55.56 \\
\hline
\end{tabular}

According to the results of Table 1, the majority of respondents chose 10 solutions from 5/7 groups, with 78 percent of their opinions rating at a very necessary level. Simultaneously, direct interviews also revealed that all respondents agreed that, in order to build physical skills for students in secondary schools in Hanoi's outskirts, all of the aforementioned solutions must be implemented together, including:

- Group 1: Raise awareness and provide knowledge about the role of physical education and the benefits of physical exercise in improving health. 
- Group 2: Renovate and upgrade material and technical foundations, implement appropriate and suitable mechanisms and policies:

- Group 3: Upgrade PE program's content and methods of teaching and examination

- Group 4: Improve the organizational structure of the Physical Education Department's administration and teaching personnel.

- Group 5: Diversify the content and forms of extracurricular sports activities in accordance with PE goals.

\section{c. Testing the necessity and feasibility of physical development solutions for students} in Hanoi suburb secondary schools

To explore the correlation between the necessity and feasibility of physical development solutions, the author conducted 108 interviews, with 25 managers from the Hanoi Department of Education and secondary schools in Hanoi's suburbs, and 83 PE teachers working at Hanoi suburban secondary schools,

To evaluate the necessity and feasibility, the author has quantified opinions by assigning points as follows:

- Very necessary; Very feasible: 3 points,

- Necessary; Feasible: 2 points,

- Somewhat necessary; Somewhat feasible: 1 point,

- Unnecessary; Infeasible: 0 points.

Table 2: Verifying the necessity of five solution groups $(\mathrm{n}=90)$

\begin{tabular}{|l|l|c|c|c|c|c|c|c|}
\hline Item & \multicolumn{1}{|c|}{$\begin{array}{c}\text { Groups of } \\
\text { solutions }\end{array}$} & $\begin{array}{c}\text { Very } \\
\text { necessary }\end{array}$ & Necessary & $\begin{array}{c}\text { Somewhat } \\
\text { necessary }\end{array}$ & Unnecessary & $\sum$ & $\bar{X}$ & Rank \\
\hline 1 & $\begin{array}{l}\text { Group 1: Raise } \\
\text { awareness and } \\
\text { provide knowledge } \\
\text { about the role of } \\
\text { physical education } \\
\text { and the benefits of } \\
\text { physical exercise in } \\
\text { improving health. }\end{array}$ & 51 & 57 & 0 & 0 & 375 & 3.47 & 1 \\
\hline 2 & $\begin{array}{l}\text { Group 2: Renovate } \\
\text { and upgrade } \\
\text { material and } \\
\text { technical } \\
\text { foundations, } \\
\text { implement } \\
\text { appropriate and } \\
\text { suitable mechanisms } \\
\text { and policies: }\end{array}$ & 46 & 62 & 0 & 0 & 370 & 3.43 & 2 \\
\hline 3 & $\begin{array}{l}\text { Group 3: Upgrade } \\
\text { PE program's } \\
\text { content and } \\
\text { methods of teaching } \\
\text { and examination }\end{array}$ & 40 & 68 & 0 & 0 & 364 & 3.37 & 3 \\
\hline
\end{tabular}




\begin{tabular}{|l|l|l|l|l|l|l|c|c|}
\hline \hline 4 & $\begin{array}{l}\text { Group 4: Improve } \\
\text { the organizational } \\
\text { structure of the } \\
\text { Physical Education } \\
\text { Department' } \\
\text { administration and } \\
\text { teaching personnel. }\end{array}$ & 35 & 73 & 0 & 0 & 359 & 3.32 & 4 \\
\hline 5 & $\begin{array}{l}\text { Group 5: Diversify } \\
\text { the content and } \\
\text { forms of } \\
\text { extracurricular } \\
\text { sports activities in } \\
\text { accordance with PE } \\
\text { goals. }\end{array}$ & 21 & 68 & 19 & 0 & 326 & 3.02 & 5 \\
\hline $\bar{X}$ & & & & & 3.36 & \\
\hline
\end{tabular}

With an average score of 3.36, the PE teachers and managers strongly valued the requirement of 5 groups of proposed solutions, as shown in Figure 2. The responses to the results were all available in two categories: very necessary and necessary. There was no vote that the solutions were unnecessary.

Table 3: Verifying the feasibility of five solution groups $(\mathrm{n}=90)$

\begin{tabular}{|l|l|c|c|c|c|c|c|c|}
\hline Item & $\begin{array}{l}\text { Groups of solutions } \\
\text { feasible }\end{array}$ & Feasible & $\begin{array}{c}\text { Some- } \\
\text { what } \\
\text { feasible }\end{array}$ & Infeasible & $\Sigma$ & $\bar{X}$ & Rank \\
\hline 1 & $\begin{array}{l}\text { Group 1: Raise awareness and } \\
\text { provide knowledge about the } \\
\text { role of physical education and } \\
\text { the benefits of physical } \\
\text { exercise in improving health. }\end{array}$ & 58 & 50 & 0 & 0 & 382 & 3.54 & 2 \\
\hline 2 & $\begin{array}{l}\text { Group 2: Renovate and } \\
\text { upgrade material and } \\
\text { technical foundations, } \\
\text { implement appropriate and } \\
\text { suitable mechanisms and } \\
\text { policies: }\end{array}$ & 62 & 46 & 0 & 0 & 386 & 3.57 & 1 \\
\hline 3 & $\begin{array}{l}\text { Group 3: Upgrade PE } \\
\text { program's content and } \\
\text { methods of teaching and } \\
\text { examination }\end{array}$ & 52 & 48 & 8 & 0 & 368 & 3.41 & 3 \\
\hline 4 & $\begin{array}{l}\text { Group 4: Improve the } \\
\text { organizational structure of the } \\
\text { Physical Education } \\
\text { Department's administration } \\
\text { and teaching personnel. }\end{array}$ & 46 & 56 & 6 & 0 & 364 & 3.37 & 4 \\
\hline 5 & $\begin{array}{l}\text { Group 5: Diversify the content } \\
\text { and forms of extracurricular } \\
\text { sports activities in accordance } \\
\text { with PE goals. }\end{array}$ & 46 & 50 & 12 & 0 & 358 & 3.31 & 5 \\
\hline
\end{tabular}




\begin{tabular}{|l|l|l|l|l|l|l|l|l|}
\hline \hline & $\bar{X}$ & & & & & & 3.46 & \\
\hline
\end{tabular}

Table 3 indicated that the feasibility of five groups of proposed solutions was completely acknowledged, with an average score $\bar{X}=3.46$. The majority of opinions concentrated on two levels: very feasible and feasible. Each group of solutions had an average score $\bar{X}$ $>3.31$. There was no opinion that the solutions were not feasible

\section{d. The detailed elaboration of five groups of physical development solutions for secondary school students in Hanoi's suburbs}

Group 1: Raise awareness and provide knowledge about the role of physical education and the benefits of physical exercise in improving health.

To ensure that administrators and teachers are fully aware of PE objectives, there should be detailed and specific plans, as well as practical and effective measures in implementing, propagating, advocating, and educating to meet the requirements, objectives, and regulations outlined in the Party and State's guiding documents.

Monitor and supervise the PE awareness-raising process. It is necessary to make each teacher aware of his dual responsibilities: while performing the task of education, retraining, and assisting students in improving their physical fitness and health, teachers must also practice their own moral qualities, self-study to improve their professional qualifications and pedagogical capacity, ensuring that the work of PE is scientific, effective, and of high quality.

Coordinating with relevant forces through diverse activities during extra- and intra- studying hours may help students to realize the proper and learning tasks, as well as create an environment for them to exchange, self-training, which is expected to raise awareness, motivation, and a positive attitude toward PE activities, thereby boosting the desire to participate in physical training and sports

Encourage and provide more opportunities for pupils to participate in more cultural, artistic, and athletic activities both inside and outside the school.

Group 2: Renovate and upgrade material and technical foundations, implement appropriate and suitable mechanisms and policies.

\section{A. Renovate and upgrade material and technical foundations}

Renovate, repair, and upgrade training facilities such as yards and gymnasiums in order to make the best use of the school's physical facilities for PE classes and extracurricular activities.

Develop a reliable policy and plans for using the yard, practice rooms for each workout object, and the use of equipment. Recommend the school on the construction plans and blueprint, ensuring that a new gymnasium, sports room, athletic field, and football field are built.

Repair and purchase new teaching and practice tools and equipment for daily and extracurricular sessions. 
Regularly check and ensure maintenance electrical and lighting systems of football fields, volleyball courts, badminton courts, multi-purpose gyms, etc.

Provide students with the chance to lend tools, make use of practice rooms, and training yards... so that they may exercise comfortably in their leisure time.

Take advantage of cutting-edge technology tools in the training and competition process. It is an extremely important approach for acquiring objective data on the quantity and quality of movements. Thanks to that, teachers can detect and rectify technical flaws quickly, which is also beneficial for students.

\section{B. Implement appropriate and suitable mechanisms and policies}

Remain the current regimes and policies, as well as design and issue detailed short-term and long-term remuneration policies to fulfill the expectations of instructors, coaches, and athletes. Mobilize financial sponsors, offer more rewards.

Encourage and reward instructors and students in a timely and satisfactory manner (in terms of spirit and material), providing incentives to support the process of training, teaching, practice, and competition.

Group 3: Upgrade PE program's content and methods of teaching and examination

\section{A. Upgrade PE program's content, increase the movement volume throughout class time}

Upgrade the program's content by focusing on the quality of practice sessions, remove the content that is no longer relevant, and introduce new ones to raise the attractiveness and students' enthusiasm in both academic and practice classes.

Build and choose movement games that are appropriate for the class content, current condition, and characteristics of secondary school students at the beginning of classes to boost the density of movements; increase students' interest in exercise, thereby training and strengthening their motor skills and physical development more effectively. Teachers are also flexible and proactive in modifying the proper amount of exercise based on practical situations.

Integrate the content of physical training into class hours and blend the content of examination into class hours.

\section{B. Modify the methods of PE teaching in favor of positivism, so increasing student engagement and creativity}

It is necessary to fully research the content of professional regulations, survey students' learning expectations; develop discipline in teaching and learning, create plans for professional groups; directly monitor, guide, and inspect teachers in the application of professional regulations; pay close attention to the criteria on education, re-education, and physical development for students. Launch and guide the emulation movement in order to innovate and flexibly utilize teaching-learning process techniques; systematically perform activities in order to improve students' engagement, initiative, 
creativity, and self-study abilities. Besides, PE teachers should be given the authority to manage, organize, and appoint gifted pupils as the leaders in PE sessions.

\section{Interpretation}

In theoretical sessions: use slideshows and movies to help students enjoy the lessons, and to absorb knowledge most effectively. Increase the use of vivid hues to highlight difficult movements.

In practice sessions (both in the regular PE class and in the extra-curricular session): Divide the practitioner into small groups, make the best use of the available yard and training equipment, and ensure that the maximum number of students participate in the activity. Improve the material, teaching methods, and practice basic and specialized exercises. Adjust the volume and duration of the exercises to suit the different student groups.

Improve the approach of structuring physical education lessons in a way of positive, student-centered learning. Diversify training methods such as circle training, interval training, and so on that are appropriate for each content and subject program. Strengthen the exercises of games and competitions in practice sessions to motivate and raise students' engagement. Optimize the ways of the training organization, focusing on group practices.

\section{Alter the ways of PE examination in favor of classifying students' health, fitness, and aptitude}

Regularly organize health and fitness checks for students (following Decision 53/2008/Regulation-Ministry of Education and Training) to categorize each student's physical fitness. It should be at least once a year at the beginning of the school year (according to the guidance of the Ministry of Health). Keep track of and manage student health monitoring records.

Organize the PE process into three groups based on the classification of students' health, fitness, and sports technical level:

Group of healthy students (category 1, 2, 3): following the general program.

Groups of weak students (category 4 and 5, including students with mobility impairments, chronic illness): being grouped by class and gender with separate programs that can take place on different days.

Group of students with athletic talent: learning and practicing in specialized classes with an optional sports program.

Create training materials and methods for each student group (in favor of gender, health status, physical condition, athletic ability).

Organize a sports talent group made up of people who desire to be professional in a specific sport and have strong stamina as well as athletic ability. This group, which can begin in first grade, is also arranged with the curriculum based on grade and gender. For students who excel in sports (who have been granted a summons or a PE exemption document by the Department of Education and Training): Have the option to be exempted from PE classes at school. The Subject Training Committee will verify, grade, 
and provide the grades to the school to serve as the basis for assessing and grading the students' PE subject.

Encourage PE teachers to update the content of teaching methods and techniques in regular classes and extracurricular hours in accordance with each group of students' health and fitness conditions. Diversify kinds of exercise and equip training sessions with appropriate specialist activities to improve general physical qualities.

Group 4: Improve the organizational structure of the Physical Education Department's administration and teaching personnel

Make a plan to forecast the number of students and teachers needed, and hire teachers to meet the standard; at the same time, assign teachers to the positions that are appropriate for their professional qualifications, ensuring adequate teaching hours in accordance with the Ministry of Education and Training's program.

Organize teacher training to improve their knowledge and skills, with a focus on scientific research and innovation in teaching material and methods. Determine the road map, content, format, and evaluation criteria, and urge PE teachers to develop active plans based on the subject's objectives.

Maximize the mobilization of financial resources both inside and outside the school, to equip practice tools and to help PE teachers foster their professional skills.

Adjust the number and quality of PE teachers and executives to suit the current condition of the school, while still adhering to the criteria issued by the Ministry of Education and Training.

Maintain effective policy regimens for PE teachers. Establish an organizational structure to manage the PE department with the goal of assigning responsibilities to each teaching staff to ensure that they fulfill the tasks and duties. Create a strategy to develop the school's extracurricular sports movement. Foster students' extracurricular exercise movements, as well as train school teams to compete in the local and national contests.

Strengthen ideological education, raise teachers' sense of responsibility for improving the quality of physical training for students, the school's sport, and physical activity movement. Organize professional activities, send staff to attend professional training courses, complete graduate training programs, especially in the summer every year.

Recruit and develop young teachers with good theoretical and professional qualifications, enthusiasm, a strong sense of responsibility, and the ability to organize large-scale sports activities to replace the old teachers who are about to retire, as well as to meet the school's demand in the coming years. Coordinate with Departments of Culture, Sports, and Tourism, as well as Sports Centers in cities, districts, and towns, to offer opportunities for PE teachers to engage in professional sports activities such as Arbitration of tournaments, sports instructor training.

Group 5: Diversify the content and forms of extracurricular sports activities in accordance with PE goals 
A. Encourage every student to take part in at least one sport. Increase the number of sports competitions to create more opportunities for students to get into

Follow the strategies given inside and outside the school, the school year plan, and the direction of the Board of Directors to organize reasonable and effective sports competition activities.

Organize traditional sports tournaments every year in order for students' sports practice to become the content of the regular and continuous cultural and sports life of students in the school, thereby creating a healthy playground for staff, teachers, and students.

Organize internal sports contests to fulfill the demands of self-training and improving health; design activities such as propaganda to promote awareness about the role of physical education in schools; Extracurricular activities, etc.

\section{B. Set up sports clubs for officials, teachers, and students of all grades in the form of socialization}

Propagate to students about a wide range of extracurricular sports activities and tournaments. Follow the guidance of the Party Committees and Board of Directors, found the sports club management board, and have particular regulations and activity programs.

Organize extracurricular activities that contribute to the improvement of $\mathrm{PE}$ subject learning material at school and physical training standards.

Found the school-wide sports clubs among professors, staff, and students. Lead programs for self-improvement.

Expand and enhance student sporting events, invite a big number of students to compete and applaud. Build teams of delegates to practice and compete regularly.

\section{Maintain and improve the quality of school teams}

Attract the attention of Party committees, authorities, and organizations on the school's sports team. Perform effectively in political and ideological education for staff and students in the team.

Keep up with the latest sports news and contest results, and obey the school's instructions.

Develop training programs for each year, quarter, month, and week; faculties and departments directly engage in professional training, assure training concepts and procedures, as well as apply new training methods.

Promote a wide range of general and professional physical training courses for gifted students.

Consolidate movement methods, construct motor skills, competition psychology, and tactical strategies for students.

Passionately enroll in contests, exchanges to increase professional credentials, abilities, and experience. 


\section{Conclusion}

Based on legal materials, practical foundations, principles, and consultation with the experts in the field of physical training for junior high schools, the author has identified five main groups of solutions with ten scientific, necessary, and feasible approaches to the physical growth of secondary school students in Hanoi's suburbs.

\section{Conflict of Interest Statement}

The author declares no conflicts of interest.

\section{About the Author}

Phung Xuan Dung has been the Institutional Council's Chairman of Hanoi University of Physical Education and Sports, Vietnam. His major is short-distance running.

\section{References}

President of the State Council (1992), Constitution of the Socialist Republic of Vietnam, National Political Publishing House, Hanoi.

President of the State Council (2013), Constitution of the Socialist Republic of Vietnam, National Political Publishing House, Hanoi.

Mai Thi Thu Ha (2014), Research on the effectiveness of aerobic exercise training and competition in extracurricular activities for primary school students, Doctoral Thesis in Educational Science, Institute of Sports Science, Hanoi.

Bui Quang Hai (2007), Research on the physical development of primary school students in the Northern province by longitudinal observation method (6 to 10 years old), $\mathrm{PhD}$ thesis in education, Institute of Sports Science, Hanoi.

Nguyen Viet Minh (2006), Innovating the teaching method of physical education to meet the requirements of reforming the general curriculum and textbooks, Collection of scientific research on health and physical education in school's 4th levels, Sports Publishing House, Hanoi, pp.79-85.

Prime Minister (2010), Decision No. 2198/QD-TTg, dated December 3, 2010, Approving the Strategy on development of physical training and sports in Vietnam until 2020.

Prime Minister (2013), Decision No. 2160/QD-TTg, dated 11/11/2013, Approving the Planning on development of physical training and sports in Vietnam until 2020, with orientation to 2030.

Prime Minister (2015), Decree No. 11/2015/ND-CP, January 31, 2015 Regulations on physical education and sports activities in schools.

Prime Minister (2016), Decision 1076/QD-TTg, dated June 17, 2016, Approving the project on the development of physical education and school sports for the period 2016-2020, with orientation to 2025.

Nguyen Ngoc Viet (2011), The change in the appearance and physical strength under the impact of intra-curricular and extra-curricular sports training for primary school students from 
6 to 9 years old in the North Central region, Thesis of Doctor of Education Science, Institute of Sports Science, Hanoi.

Stephen J. Virgilio, 1997, Fitness Education for Children- A team approach Publisher Human Kinetics, in New York, page 3-4.

Kholodov Zh. K., Kuznetsov V.S., Theory and Methods of Physical Education and Sports" (2000). Proc. Manual for students of the Institute of Physical Culture, Moscow, Academician.

Creative Commons licensing terms

Authors will retain the copyright of their published articles agreeing that a Creative Commons Attribution 4.0 International License (CC BY 4.0) terms will be applied to their work. Under the terms of this license, no permission is required from the author(s) or publisher for members of the community to copy, distribute, transmit or adapt the article content, providing a proper, prominent and unambiguous attribution to the authors in a manner that makes clear that the materials are being reused under permission of a Creative Commons License. Views, opinions and conclusions expressed in this research article are views, opinions and conclusions of the author(s). Open Access Publishing Group and European Journal of Physical Education and Sport Science shall not be responsible or answerable for any loss, damage or liability caused in relation to/arising out of conflict of interests, copyright violations and inappropriate or inaccurate use of any kind content related or integrated on the research work. All the published works are meeting the Open Access Publishing requirements and can be freely accessed, shared, modified, distributed and used in educational, commercial and non-commercial purposes under a Creative Commons attribution 4.0 International License (CC BY 4.0). 